\title{
Radioactive studies of phytoplankton in the cooling reservoir of the Beloyarsk atomic power station
}

\author{
V.P. Guseva and M.Ya. Chebotina \\ Institute of Plant and Animal Ecology, Ural Division RAS, \\ 8 Marta Str. 202, 620144 Ekaterinburg, Russia
}

\begin{abstract}
The paper gives data on the species composition, abundance and biomass of the phyto and zooplankton in the cooling reservoir of the Beloyarsk atomic power station. We discuss the effect of the cooling system on the plankton organisms, the effect of the discharged heated water on the condition and accumulative ability of the plankton. We studied daily dynamics of radionuclide accumulation and estimated the contribution of the phytoplankton to the total stock of radionuclides in the Beloyarsk reservoir.
\end{abstract}

\section{INTRODUCTION}

Due to the ability for quick reproduction and creation of big biomass, plankton organisms are very important for the energy and matter turnover in the water ecosystems and for the self-purification of ponds from chemical and radioactive pollution [4]. The data on accumulation of radionuclides and other pollutants in plankton are very few in the literature, evidently because of sampling difficulty and the dynamics of spatial-temporal quantitative characteristics of the plankton. To estimate the radioecological role of phyto- and zooplankton, of special interest are studies on cooling reservoirs into which low- radioactive water from atomic power stations is discharged.

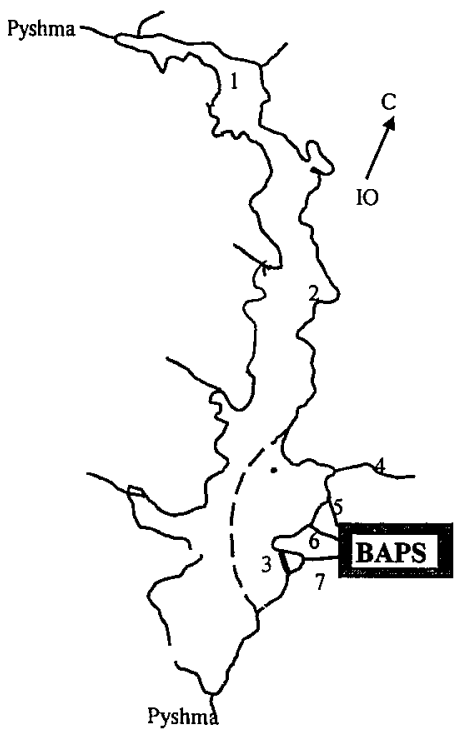

Figure 1: Scheme of the Beloyarsk water reservoir

1 - region of the upper waters;

2 - Shchuchy bay;

3 - Teply ("Warm") bay;

4 - by-pass channel;

5 - run-off channel;

6 - water intake channel;

7 - discharge channel.

\section{PLACE AND OBJECT}

Our research was conducted at the Beloyarsk reservoir in the Middle Urals $60 \mathrm{~km}$ east of Ekaterinburg. The pond as made in 1959-1963 by the Pyshma river-bef regulation, $75 \mathrm{~km}$ from its source. The river belongs to the Ob-Irtysh basin, it is a right tributary of the Tura, which flows into the Tobol, a tributary of the Irtysh. The reservoir is about $20 \mathrm{~km}$ long, $3 \mathrm{~km}$ wide in the region of the power station, 15-20 m deep in the Pyshma waterway. The water table makes about $47 \mathrm{~km}^{2}$. 
The Beloyarsk power station (BAPS) is situated on the left bank of the reservoir, $7 \mathrm{~km}$ north of the dam (Figure1). It was put into operation in 1974. The first unit was removed from service in 1981, the second one operated from 1967 to 1989. In 1980 the third unit was put into operation [1]. The object of our research was the plankton of the cooling reservoir.

\section{RESULTS}

The inventory revealed 120 algae taxa and 25 species of zooplankton organisms. Aphanizomenon flos-aquae (L.) Ralfs, Microcystis aeruginosa Kütz. emend Elenk., Coelastrum microporum Näg., Oocystis submarina Lagerh., Pediastrum duplex Meyen., Ceratium hirundinella (O.F.M.) Bergh., Cryptomonas marssonii Skuja dominated among microalgae, Daphnia pulex De Geer., D. cristata Sars., Diaptomus graciloides Lill. - among zooplankton organisms.

The average abundance and biomass of phytoplankton in the reservoir made 184 millions cells $/ \mathrm{l}$ and $20 \mathrm{mg} / \mathrm{l}$ correspondingly, those of zooplankton were 131 thousand ind $/ \mathrm{m}^{3}$ and $5 \mathrm{~g} / \mathrm{m}^{3}$.

The passage of water through the cooling system does not influence the species composition of phyto- and zooplankton. 173 tons of phytoplankton and 11 tons of zooplankton are suck in the cooling facilities daily. $62 \%$ of phytoplankton and $45 \%$ zooplankton pass through the spillway channel back into the reservoir undamaged, whereas 38\% (65 tons/day) and 55\% (6 tons/day) correspondingly perish in the cooling system. Considering that the water volume in the Beloyarsk reservoir is 265 millions $\mathrm{m}^{3}$ one can suppose that during 4 months all this water volume passes through the cooling system. During this period in summer average 7800 tons of phyto- and 720 tons of zooplankton perish in addition to natural mortality. The dead organisms are transformed into detrite partly returning to the reservoir with the heated water and partly retained in the cooling system.

In various years the content of radionuclides in the plankton from the water intake and the discharge channels varied in a wide range. During operation of the 2 nd and the 3 rd units of the power station (1985-1986) radionuclide concentrations in most cases were higher in the plankton from the discharge channel than those from the water intake channel. Perhaps that resulted from the leakage in the heat exchange facilities during operation of the 2 nd unit. After its removal from service no significant changes between the radionuclide concentrations in the plankton from both channels were observed (Table 1).

Investigation of the chemical composition of the plankton before and after its passage through the cooling system revealed its enrichment with macro- and microelements: $Z r$ increased 4 times, $\mathrm{Si}-5$ times, $\mathrm{Sn}, \mathrm{Re}, \mathrm{Pb}, \mathrm{Co}, \mathrm{Ca}-7$ times, $W, \mathrm{~V}, \mathrm{Fe}, \mathrm{Cu}-10-13$ times, $\mathrm{Mg}, \mathrm{Cr}, \mathrm{Ti}-18-20$ times, $N i-35$ times, $M n-215$ times. We did not manage to reveal if these were radioactive or stable, but the fact evidenced about additional contamination of the Beloyarsk reservoir with the elements operation of the 2 nd unit.

Table 1: Concentration of radionuclides in the plankton from the water intake and the discharge channels, $\mathrm{Bq} / \mathrm{kg} \mathrm{dry}$ mass.

\begin{tabular}{|c|c|c|c|c|c|c|}
\hline \multirow{2}{*}{ Year } & \multicolumn{3}{|c|}{ Water intake } & \multicolumn{3}{c|}{ Discharge } \\
\cline { 2 - 7 } & ${ }^{60} C o$ & ${ }^{90} S r$ & ${ }^{137} C s$ & ${ }^{60} C o$ & ${ }^{90} S r$ & ${ }^{137} C s$ \\
\hline 1985 & 60 & 29 & 98 & 1310 & 150 & 1240 \\
\hline 1986 & 1150 & 26 & 470 & 1380 & 23 & 1040 \\
\hline 1990 & 122 & 10 & 247 & 125 & 16 & 255 \\
\hline 1991 & 151 & 12 & 151 & 140 & 22 & 152 \\
\hline
\end{tabular}

After the passage through the cooling system the water falls into the Teply bay. The research revealed differences in the predominant algae species between the heated zone (the Teply bay) and the control (the Shchuchy bay, $7 \mathrm{~km}$ from the power station towards the upper waters), but the abundance and biomass values of phytoplankton in the compared regions were rather close. The average abundance of algae during the research period in the compared areas was 25, 1 and 24,9 
millions cells / 1 , the biomass made 8,7 and $9,1 \mathrm{mg} / \mathrm{l}$, correspondingly. The statistical treatment of the data using the $t$ criterion by the method of pair comparison in the log scale did not reveal any significant differences between the compared areas. Thus, there are favorable conditions in the Teply bay for the recreation of the abundance and biomass of the phytoplankton after its passage through the cooling facilities. The average abundance of zooplankton in the Teply bay during the period of investigations was 4 times, its biomass was 7 times lower than in the control thus evidencing of suppression of zooplankton in the heated zone. The concentration of radionuclides in the Teply bay varied in the following range: ${ }^{60} \mathrm{Co}$ - from 20 to $1000,{ }^{90} \mathrm{Sr}$ - from 6 to $400,{ }^{137} \mathrm{Cs}-$ from 30 to $900 \mathrm{~Bq} / \mathrm{kg}$ of dry mass. The statistical treatment of the results revealed significant changes between the Teply and the Shchuchy bays (Table 2). The differences may result either from the effect of higher water temperature in the discharge zone or from an additional entry of radionuclides to the Teply bay from the cooling facilities through the discharge channel. Upstream on the right bank of the reservoir there are the run-off and the by-pass channels carrying increased quantities of radionuclides. Passing by the water intake zone they are suck into the cooling facilities and then enter the Teply bay through the discharge channel $[2,3]$.

We observed that the accumulative ability of phytoplankton organism depended on the hour of the day. Thus, between 4 and 6 p.m. the content of each of the three examined radionuclides decreased twice compared to other hours. During the same time interval, the abundance and the biomass increased twice or thrice. This can be explained by effective warming up of the water

Table 2: Concentration of radionuclides in the Teply (1) and the Shchuchy (2) bays of the Beloyarsk reservoir, Bq $/ \mathrm{kg}$ dry mass

\begin{tabular}{|r|c|c|c|c|c|c|}
\hline \multirow{2}{*}{ Sampling date } & \multicolumn{2}{|c|}{${ }^{60}$ Co } & \multicolumn{2}{c|}{${ }^{90} S r$} & \multicolumn{2}{c|}{${ }^{137} C s$} \\
\cline { 2 - 7 } & 1 & 2 & 1 & 2 & 1 & 2 \\
\hline 1986 г., June & 973 & 136 & 78 & 40 & 882 & 264 \\
\hline July & 107 & 85 & 174 & 69 & 196 & 129 \\
\hline August & 602 & 310 & 316 & 54 & 544 & 614 \\
\hline Average & 561 & 177 & 189 & 54 & 540 & 336 \\
\hline 1988 r., June & 278 & 28 & 36 & 7 & 604 & 131 \\
\hline July & 33 & 19 & 6 & 12 & 47 & 37 \\
\hline August & 53 & 54 & 10 & 8 & 88 & 204 \\
\hline Average & 121 & 34 & 17 & 9 & 246 & 124 \\
\hline
\end{tabular}

thickness and by an optimal light between 4 and $6 \mathrm{p}$. $\mathrm{m}$. which stimulate an intensive increase in the number of the dividing cells exceeding the decrease due to their deaths. The inverse correlation between the phytoplankton biomass and the radionuclides concentration in the whole plankton may be explained by the effect of "dilution" of radionuclides in the plankton mass due to quick increase of abundance of microalgae young cells. To estimate radionuclides accumulation in the plankton of whole reservoir, it was interesting to estimate their concentrations in the central part of the reservoir. For this purpose plankton was taken from the lower (from the Teply bay to the Biophysical station) and the upper parts (from the Shchuchy bay to the upper waters). Average concentrations of the radionuclides in the compared areas were rather close: $220 \mathrm{~Bq} / \mathrm{kg}{ }^{60} \mathrm{Co} ; 6,5$ $\mathrm{Bq} / \mathrm{kg}{ }^{90} \mathrm{Sr}$, and $53 \mathrm{~Bq} / \mathrm{kg}{ }^{137} \mathrm{Cs}$.

Table 3 : Distribution of radionuclides in the main components of the Beloyarsk reserve

\begin{tabular}{|l|c|c|c|c|c|c}
\hline \multirow{2}{*}{ Component } & \multicolumn{2}{|c|}{${ }^{60} \mathrm{Co}$} & \multicolumn{2}{c|}{${ }^{90} \mathrm{Sr}$} & \multicolumn{2}{c}{${ }^{137} \mathrm{Cs}$} \\
\cline { 2 - 7 } & $\mathrm{MBq}$ & $\%$ & $\mathrm{MBq}$ & $\%$ & $\mathrm{MBq}$ & $\%$ \\
\hline Water & 6600 & 2,7 & 9900 & 8 & 12000 & 1,8 \\
\hline Ground & 238000 & 96,6 & 114000 & 91,8 & 656000 & 98 \\
\hline Plants & 26 & 0,01 & 12 & 0,01 & 15 & 0,002 \\
\hline Plankton & 736 & 0,3 & 109 & 0,09 & 709 & 0,11 \\
\hline
\end{tabular}


During the investigation period, the average stock of radionuclides in the plankton was: 736 $\mathrm{MBq}{ }^{60} \mathrm{Co}, 109 \mathrm{MBq}{ }^{90} \mathrm{Sr}, \quad 709 \mathrm{MBq}{ }^{137} \mathrm{Cs}$. Based on the obtained data we calculated the contribution of phytoplankton to the total balance of radionuclides in the Beloyarsk reservoir (Table 3). The content of radionuclides in the plankton on the whole was more than in higher water plants from the cooling reservoir.

We compared concentrations of ${ }^{60} \mathrm{Co},{ }^{90} \mathrm{Sr}$, and $137 \mathrm{Cs}$ in the plankton with those in other components of the Beloyarsk reservoir. Chladophora and salty ground were chosen because they are widely spread in the reservoir, show relatively high accumulation ratios and are therefore good bioindicators of radioactive pollution of the reservoir. Table 4 shows that concentrations and accumulation ratios are of the same order for all objects studied.

Table 4: Radionuclide concentrations and accumulation ratios (A.R.) in the plankton, Chladophora and silty ground in the investigated zone of the Beloyarsk reserve (per dry mass); A.R.- ratio of the radionuclide concentration in the object to that in water.

\begin{tabular}{|l|c|c|c|c|c|c|}
\hline \multicolumn{1}{|c|}{ Object } & ${ }^{60} \mathrm{Co}, \mathrm{Bq} / \mathrm{kg}$ & A.R. & ${ }^{90} \mathrm{Sr}, \mathrm{Bq} / \mathrm{kg}$ & A.R. & ${ }^{137} \mathrm{Cs}, \mathrm{Bq} / \mathrm{kg}$ & A.R. \\
\hline Plankton & 270 & 13500 & 40 & 930 & 260 & 5910 \\
\hline Chladophora & 155 & 7750 & 70 & 1630 & 120 & 2730 \\
\hline Silty ground & 310 & 15500 & 40 & 930 & 800 & 18200 \\
\hline
\end{tabular}

\section{CONCLUSION}

Our research confirms great role of plankton in radionuclides migration in reservoirs affected by atomic power stations.

\section{Acknowledgements}

The work was supported by RFFR regional grant $01-05-96445$. We also thank the organizers of international congress for their help and publication of our article.

\section{References}

[1] Chebotina M.Ya., Trapeznikov A.V., Trapeznikova V.N., Kulikov N.V., Radioecological studies of the Beloyarsk Reservoir (Ural Nauka Press, Sverdlovsk, 1992) 84 p.

[2] Guseva V.P., Chebotina M.Ya., Ecology 1 (2000) pp. 26-31.

[3] Guseva V.P., Chebotina M.Ya., Trapeznikov A.V., Kulikov N.V., Ecology 5 (1989) pp. 73-75.

[4] Mordukhai-Boltovskoi F.D., The Ecology of Organisms Inhabiting Cooling Reservoirs Nauka Press, Leningrad, 1975) pp. 7-69. 